FINAL VERSION: Carrero-Pazos, M., Bustelo-Abuín, J., Barbeito-Pose, V., RodríguezRellán, C. (2020). Locational preferences and spatial arrangement in the barrow landscape of Serra do Barbanza (North-western Iberia). Journal of Archaeological Science: Reports 31. https://doi.org/10.1016/i.jasrep.2020.102351

\title{
Locational Preferences and Spatial Arrangement in the Barrow Landscape of Serra de Barbanza (North-western Iberia)
}

Miguel Carrero-Pazos, corresponding author, miguel.carrero.pazos@gmail.com

University of Santiago de Compostela, Department of History, GEPN-AAT

Praza da Universidade 1, 15782 Santiago de Compostela, Spain

Julián Bustelo Abuín, julianbustelo17@gmail.com

University of Santiago de Compostela, Department of History, GEPN-AAT

Praza da Universidade 1, 15782 Santiago de Compostela, Spain

Víctor Barbeito Pose, victor@centroarqueoloxicodobarbanza.org

Centro Arqueolóxico do Barbanza

Neixón, Nine s/n.15991 Cespón, Boiro

Carlos Rodríguez-Rellán, carlos.rellan@,fulbrightmail.org

University of Seville, Department of Prehistory and Archaeology, ATLAS

Doña María de Padilla, 41004 Seville, Spain

\begin{abstract}
As anywhere else, GIS is an essential tool in Galician archaeological research for examining and analysing spatial data. This is something quite clear in megalithic studies where in the last years these methods have been used for contrasting hypotheses regarding locational preferences drawn from fieldwork. As such, in this paper, a study of locational patterns of the megalithic sites located in the flattened top territories of $\mathrm{A}$ Serra do Barbanza (Galicia, NW Spain) is carried out. Using a site-predictive modelling approach, several environmental covariates were analysed to see their role in the distribution of mounds. Next, we study the clustering of megaliths via second-order modelling. The results obtained led us to conclude that the distribution of sites shows an aggregation at very local scales, a trend that can only be explained by intended site spacing dynamics that may have taken place over millennia. Using significance testing via Monte Carlo Simulation, the outcomes of this research allowed us to identify possible preferences regarding the selection of particular landscapes for the location of
\end{abstract}


FINAL VERSION: Carrero-Pazos, M., Bustelo-Abuín, J., Barbeito-Pose, V., RodríguezRellán, C. (2020). Locational preferences and spatial arrangement in the barrow landscape of Serra do Barbanza (North-western Iberia). Journal of Archaeological Science: Reports 31. https://doi.org/10.1016/i.jasrep.2020.102351

Galician megaliths but also modelling the potential impact of tradition, a tendency by which mounds fostered the subsequent construction of megaliths in the nearby areas.

\section{Keywords}

Galicia, mound, site predictive modelling, Monte Carlo Simulation, point pattern analysis, GRASS GIS, R Statistics

\section{Introduction}

Galicia is one of the areas of the Atlantic façade of Western Europe with the highest density of megalithic constructions, their number surpassing the 3,000 mounds in a territory of 29 thousand $\mathrm{km}^{2}$ (slightly larger than Wales). This number can be increased until more than 7,000 if we use the data from the Official Catalogue from Galician government, although this catalogue which departed from the 1980s has problems that were already pointed out elsewhere (Carrero-Pazos 2017). This intensity of occupation has been emphasized by researchers since the classic work of G. Leisner (1938), who presented one of the first distribution map of the Galician megaliths, although focusing on the coastal areas, or F. López Cuevillas (1973: 54), who pointed out how Galicia has a density of megalithic sites higher than other territories in Spain.

These pioneering approaches prompted an incipient interest on the spatial dimension of megaliths. Thus, A.A. Rodríguez Casal proposed new distribution maps in 1978 and 1990, paying special attention to inland Galicia, which remained virtually unexplored at that time. Proper locational studies started to appear then, leading to the development of an interpretative model of the Galician megalithic phenomenon (Bello Diéguez et al. 1982a, 1987; Criado Boado 1988a, 1988b). These works were based on prospection surveys carried out by F. Criado Boado in the Curtis-Sobrado area (eastern A Coruña) (Criado Boado et al. 1980, 1984a, 1984b) and in the Serra do Barbanza, in the western coast of Galicia (Criado Boado et al. 1986, 1988). The research will reach a full swing during 1990s and early 2000s, thanks to further surveys on the Barbanza Peninsula (Villoch 2000) and in many other areas of the Galician territory (Rodríguez Casal 1997; Rodríguez Casal et al. 1998; Eguileta Franco, 1999; Fábregas Valcarce \& Vilaseco Vázquez 2002; Fábregas Valcarce et al. 2003, 2004) that helped to complete the distribution map of the Galician megaliths. 
FINAL VERSION: Carrero-Pazos, M., Bustelo-Abuín, J., Barbeito-Pose, V., RodríguezRellán, C. (2020). Locational preferences and spatial arrangement in the barrow landscape of Serra do Barbanza (North-western Iberia). Journal of Archaeological Science: Reports 31. https://doi.org/10.1016/i.jasrep.2020.102351

These efforts, together with that of countless individual researchers, have led to a research inventory that -in 2017- comprised 3,305 megalithic sites, ${ }^{1}$ a catalogue which is being improved with new findings (Fig. 1).

[Caption]. Figure 1. Current distribution of megalithic monuments in Galicia, NW Spain (University of Santiago de Compostela, GEPN-AAT).

Concerning GIS methods, their introduction in Galician archaeological research was mainly after the 2000s, and specifically in other historical periods, such as Iron Age (see e. g. Parcero-Oubiña 2000; Fábrega-Álvarez 2004; Parcero-Oubiña, Fábrega-Álvarez 2006; Fábrega-Álvarez \& Parcero-Oubiña 2007) or Bronze Age rock art (e. g. Rodríguez Álvarez 2012; Rodríguez Rellán \& Fábregas Valcarce 2015). Concerning the megalithic studies, we had to wait until recent times where new researches are appearing, specifically in locational patterns and quantitative modelling (e. g. Llobera 2015; Rodríguez Rellán \& Fábregas Valcarce 2015, 2019; Carrero-Pazos 2018a,b; Fábregas Valcarce et al. 2018; Carrero-Pazos \& Rodríguez Casal 2019;).

\section{Serra do Barbanza, a core area of research in Galician megaliths}

The Galician megalithic phenomenon, and especially the Barbanza peninsula, has been scientifically researched since late nineteenth century, although genuine spatial approaches came to light in late 1980s and mostly in 1990s. As stated by FábregasValcarce et al. (2018), the most up-to-date inventory for the Peninsula comprises a total of 209 mounds. The upland valleys ("Chans do Barbanza"), a small $7 \mathrm{~km}^{2}$ flattened top mountain range, concentrated a significant attention by research for long time, although it only holds $20 \%$ of the mounds in the region (Bustelo Abuín 2017). In this context, several works from Landscape Archaeology analysed the spatial arrangement of the megaliths linking them to the movement to/from/across the plateau (Criado Boado et al. 1994) and placing them within a network of natural transit which structured the movement across all the peninsula (Criado Boado \& Villoch Vázquez 2000: 199-200).

\footnotetext{
${ }^{1}$ Data gathered from our megalithic study group at the University of Santiago de Compostela, GEPNAAT, based on the results of 3 projects directed by prof. Antón A. Rodríguez Casal and funded by Galician Government: "Megalitismo e xeoloxía. Arqueoloxía e ecoloxía da cultura dolménica na provincia de Lugo" (1994-1996)"; "Arqueoloxía e ecoloxía do fenómeno tumular e megalítico no Sur de Galicia (1998-2000)"; Arqueoloxía e ecoloxía do fenómeno tumular e megalítico na Galicia noroccidental (2004-2007)".
} 
FINAL VERSION: Carrero-Pazos, M., Bustelo-Abuín, J., Barbeito-Pose, V., RodríguezRellán, C. (2020). Locational preferences and spatial arrangement in the barrow landscape of Serra do Barbanza (North-western Iberia). Journal of Archaeological Science: Reports 31. https://doi.org/10.1016/i.jasrep.2020.102351

These former approaches were carried out in a pre GIS era, so were built from intensive field survey projects, proposing locational patterns out of common-sense interpretations (Lake, Woodman 2003: 690). A second group of studies concerning Serra do Barbanza are those that used GIS and spatial statistics for the analysis and quantification of these locational patterns, all of them in recent times. The proposal of M. Llobera (2015) concerning the mobility and visibility dynamics in the whole peninsula of Barbanza is the main starting basis. This was subsequently followed by works which examined the role of pathways and other variates in the location of megaliths and petroglyphs in this very same area (Rodríguez Rellán \& Fábregas Valcarce 2015, 2019; Bustelo Abuín, et al. 2017; Fábregas Valcarce et al. 2018).

Despite all of the tradition of research, there were no dating programs in the area which allow us to reconstruct a timescale of the structures. Some proposals have recently pointed out the existence of two moments in the cluster of sites (early/recent), although based on theoretical assumptions rather than on contrasted archaeological research (see e.g. Criado-Boado, Senín-Vuelta 2017).

A representative dating program is truly a big challenge for the megalithic research in North-western Iberia. Future research in the Barbanza region has to face this problem to allow the reconstruction of the biography of the whole necropolis, to decide whether the barrows are contemporary or not, related, similar to each other, or even discard them if they are not prehistoric barrows, in the case of earthen barrows. This is a classic issue in mound research (see e.g. Hewitt et al. 2011), and there are very well known cases of "false positives" in Galicia already known, specially under rescue archaeology (see Carrero-Pazos 2017).

The lack of radiocarbon dates is, generally, a big question in the megalithic research of North-western Iberia, something common other Iberian and European areas (see e.g. Bourgeois 2013). In the case of Galicia, we currently have 56 radiocarbon dates for a database of more than 3,000 sites, a number which is being under improvement considering rescue excavations and ongoing university projects (Barbeito Pose et al. 2018). The lack of dating is enhanced by another problematic issue: the poor state of preservation of the archaeological structures, mainly affected by ancient destructions and violations. This further difficult the introduction of the time variable in our research, as currently the majority part of the sites are barrows with no rock structures. This way, we have to assume that our sites are contemporary, as it is traditionally done 
FINAL VERSION: Carrero-Pazos, M., Bustelo-Abuín, J., Barbeito-Pose, V., RodríguezRellán, C. (2020). Locational preferences and spatial arrangement in the barrow landscape of Serra do Barbanza (North-western Iberia). Journal of Archaeological Science: Reports 31. https://doi.org/10.1016/i.jasrep.2020.102351

(Villoch Vázquez, Criado Boado, 2000; Llobera 2015). Consequently, assuming stationarity in the group of sites is accepted when temporal uncertainty arises, at least until we have a very detailed dating scheme for the area (see e.g. Bevan et al. 2013; Bourgeois 2013 for similar cases).

\section{Study area and archaeological dataset}

The Barbanza Peninsula is the northernmost of the peninsulas located in the Western Coast of Galicia. Following a NE-SW orientation, its main geographical feature is the Serra do Barbanza, a horst structure conformed in the late Tertiary that splits the peninsula in half: the slopes and coastal platforms located to its North and South-East (Nonn 1966; Guitián Rivera 1978). The Serra do Barbanza has an average altitude of 500 m.a.s.l., its upper part being dominated by small plateaus (the aforementioned "Chans do Barbanza") separated by ridges and hills of gentle slopes and crossed by several river valleys that provide water and fresh grazing almost all year round. For this paper, however, we have defined a study area of $82.38 \mathrm{~km}^{2}$, circumscribed to those upland sectors within the Sierra -above 200 meters high- (Fig. 2). Current research in this area is showing that if we take the whole peninsula there are more mounds $(66 \%$ of the data) on the coastal platform (0-200 m.a.s.1.) than on uplands (Bustelo et al. 2017), although in this paper we wanted to keep our attention in the area that traditionally concentrated the focus of research, as we have seen before. These points out a revision of the traditional hypothesis which considers the megaliths being located eminently in upland landscapes (as stated by Fábregas et al. 2018). Also, it should be noted that there are other factors which certainly have influenced the current distribution of mounds, such as the intensity of lowland occupation, which has probably removed or flattened a high number of monuments (Taylor 1984). The analysis of the influence of historical human occupation, such as farming, is a pending study for the future.

[Caption]. Figure 2. Above: Selected study area, the highlands of Sierra de Barbanza (above 200 meters high). Below: the megalith of Arca da Barbanza, and a view from the Sierra towards the Ría de Muros-Noia (NW).

The archaeological data used in this research comprises a total of 62 megaliths (of the total 209 currently known in the whole peninsula). Such inventory is the result of 
FINAL VERSION: Carrero-Pazos, M., Bustelo-Abuín, J., Barbeito-Pose, V., RodríguezRellán, C. (2020). Locational preferences and spatial arrangement in the barrow landscape of Serra do Barbanza (North-western Iberia). Journal of Archaeological Science: Reports 31. https://doi.org/10.1016/i.jasrep.2020.102351

decades of fieldwork carried out by different researchers and subsequently expanded and revised with further fieldwork and ground-truthing (LiDAR) by some of us (V. B. in the framework of the project OzoNO - HAR2015-67435-P). From the selected 62 megaliths, just a few preserve some kind of structure (not just earthen mounds), ranging from individual slabs, chambers with corridor or cists. Based on fieldwork and comparative analyses with dated monuments, the researchers have developed a typological classification of monuments which allow us to reconstruct a general chronological framework for Galician megalithism. An early phenomenon composed by single chambers (4500-3500 BC); a phase of explosion by 3500-2500 BC, characterised by corridor dolmens, and a late megalithism (2500-1800 BC) with small cists or burials without above-ground structures.

\section{Locational model and definition of covariates}

In this paper, site predictive modelling is the method used to analyse the role of several locational variables in the distribution of megaliths in Serra do Barbanza. Site predictive modelling is normally understood as the method which allows the prediction of a value of one dependent variable (probability of presence) in a non-sampled location, using one or more independent variables. In Archaeology, this method has been traditionally used to know new archaeological sites, based on a quantitative estimation of the locational preferences of the sites in a defined area (Kvamme 1983, 1990; Kohler, Parker, 1986; Jude, Sebastian 1988; Westcott, Brandon 2000; Conolly, Lake, 2006. See Fernández Cacho, Rodrigo Cámara 2003 for the Spanish pioneer project MAPA).

To that vein, ten covariates were selected from previous works and modelled thanks to GIS methods, as summarised in Table $\mathbf{1 .}^{2}$

[Caption]. Table 1. Variables of the locational model of the megalithic culture in Galicia managed by literature, and setup in a GIS environment.

\footnotetext{
${ }^{2}$ Pedological characteristics were not considered in this paper as the analysis of this variable needs reliable data obtained through paleoenvironmental analyses conducted on a local scale, which we do not currently have. The relationship between mounds and other natural features -such as rock outcrops- and archaeological remains - petroglyphs- was not analysed in this work neither (For such an approach see Rodríguez Rellán \& Fábregas Valcarce 2015, 2019).
} 
FINAL VERSION: Carrero-Pazos, M., Bustelo-Abuín, J., Barbeito-Pose, V., RodríguezRellán, C. (2020). Locational preferences and spatial arrangement in the barrow landscape of Serra do Barbanza (North-western Iberia). Journal of Archaeological Science: Reports 31. https://doi.org/10.1016/i.jasrep.2020.102351

As former approaches (Rodríguez Rellán \& Fábregas Valcarce 2015; Carrero-Pazos 2017), the geology was studied through a reclassification of the official MAGNA geological map developed by the Geological and Mining Institute of Spain (IGME). The altitude and slope were derived from a $5 \mathrm{~m}$ resolution DEM built from LiDAR data, obtained from the Spanish National Geographic Institute (IGN) (Fig. 3: A). The topographic prominence (understood here in the sense of Llobera 2001) was modelled via the topographic position index algorithm in SAGA GIS (Guisan et al. 1999; Weiss 2001; Wilson \& Gallant 2000). Since this analysis is scale-dependant, it is recommended to conduct a comparative approach where several radii are considered (Knitter \& Nakoinz 2018: 54). For this paper, both local (100 m) and larger scales (500 m) have been used (see De Reu et al. 2011 for an extensive work on this variable) (Fig. 3: B).

The watershed map was calculated in GRASS GIS 7.0.4 (r.watershed) with a comparative approach between local and global basins, selecting an 8000 cell threshold (minimum size of exterior watershed basin) which provided the theoretical edges of the main watershed basins in this area (see Fig. 3: A). The results match fairly well the main watersheds that drain to the coast (see Fábregas Valcarce \& Rodríguez Rellán 2012). Then, the relationship of megaliths, watershed edges and rivers was estimated via Euclidean distance (r.distance), generating a raster map of distances from both rasters (Fig. 3: C).

[Caption] Figure 3. Some of the first order covariates modelled in this paper. A: Elevation, with watershed edges. B: Topographic prominence at larger scale $(500 \mathrm{~m})$. C: Distance to watershed edges (meters). D: Total viewshed.

On the other hand, the relation of mounds with flooding areas was modelled, using the topographic wetness index in SAGA GIS (Boehner et al. 2002). Regarding the visibility, we wanted to see if mounds were systematically erected in the most visible parts of the landscape. To know that we followed the total viewshed approach proposed by M. Llobera (2003; Llobera et al. 2010) -although we are aware that this variable needs further development (see e. g. García Sanjuán et al. 2006; Wright et al. 2014; Brughmans et al. 2018; Carrero-Pazos 2018b; Fábrega-Álvarez \& Parcero-Oubiña 
FINAL VERSION: Carrero-Pazos, M., Bustelo-Abuín, J., Barbeito-Pose, V., RodríguezRellán, C. (2020). Locational preferences and spatial arrangement in the barrow landscape of Serra do Barbanza (North-western Iberia). Journal of Archaeological Science: Reports 31. https://doi.org/10.1016/i.jasrep.2020.102351

2019). The total viewshed analysis was done over the total number of cells in the $5 \mathrm{~m}$ DTM (3.295.323 of points), using GRASS GIS 7.0.4. (Fig. 3: D).

A crucial aspect regarding visibility is whether we can assume that the current landscape properties are similar to the Neolithic period. As stated by Criado Boado and Villoch Vázquez (2000: 196), the reconstruction of the prehistoric plant cover based upon pollen analysis indicates that the area was less degraded in the megalithic period than today, although there was an equal prominence of open vegetation. So, although sparingly, we can assume that current visual conditions between mounds, in a context of open and small vegetation, would fairly match to those in the Neolithic period.

Finally, based also in the work by M. Llobera (2015), who analysed the dynamics of mobility and visibility in this area, a study of the natural transit network was carried out by generating a density map of least cost paths. This approach, developed as well by $\mathrm{C}$. Rodríguez Rellán and Fábregas Valcarce $(2015,2018)$, allows to get a network of least cost paths displaying areas of special concentration of pathways (White \& Barber 2012) that may be interpreted as sectors with a higher potential transit intensity. In this case, we modelled a final network comprising 5.800 routes that were converted into a raster map through kernel density estimation.

\section{First-order dynamics}

The distribution map shows a clustered pattern over the study area (see Fig. 2). This means that the intensity of sites (the expected number of points per unit area) reflects spatial variation so we can use statistical methods to estimate how this spatial variation is (Baddeley et al. 2016). This is interesting as will show if the megalith's distribution depends on the values of specific covariates, for instance, whether sites prefer a particular altitude or not. Thus, the approximation chosen in this paper for analysing the monovariate pattern is the study of the intensity through a non-parametric summary of each univariate relationship between the dependent variable (presence of sites) and the different covariates. This was done in $R$ Statistics (RStudio version 1.1.463) (R Development Core Team 2008) using the function rhohat from the spatstat package (Baddeley et al. 2016: 180) (Figure 4). 
FINAL VERSION: Carrero-Pazos, M., Bustelo-Abuín, J., Barbeito-Pose, V., RodríguezRellán, C. (2020). Locational preferences and spatial arrangement in the barrow landscape of Serra do Barbanza (North-western Iberia). Journal of Archaeological Science: Reports 31. https://doi.org/10.1016/i.jasrep.2020.102351

[Caption] Figure 4. Intensity as an estimated function giving mound density as a function of the different covariates (solid lines show function estimate while grey shading is pointwise $95 \%$ confidence band).

The study of the intensity allows us to get a rough idea of the characteristics of megalithic landscapes in the study area. We can compare these results with the percentage of the study area per elevation (in m.a.s.1.) (Figure 5): $300-17.38 \%$; 400 $24.39 \% ; 500-22.87 \% ; 600-29.48 \% ; 700-5.88 \%$. The results indicate that megaliths are more likely to be found in elevations ranging from 500 to $600 \mathrm{~m}$ ASL and in areas of gentle slopes, zones which represent a $22.87 \%$ of the total study area.

[Caption]. Figure 5. Altitudinal distribution of mounds (line) compared to that of the terrain in the study area (bars).

Also, mounds are close to watershed edges and in areas with topographic significance at large scales, which suggests that visibility played an important role in explaining their location, as former approaches have already suggested (Llobera 2015; Fábregas Valcarce et al. 2017; Fábregas Valcarce \& Rodríguez Rellán 2019).

To assess these informal conclusions about preferences regarding site-location, we conducted a multivariate regression model (as done by Bevan et al. 2013). Prior to that, a Pearson correlation's test was carried out over the set of variables in order to avoid overparameterization. The results pointed out the pertinence of removing the topographic prominence index $(100 \mathrm{~m})$ from the model (Figure 6).

[Caption] Figure 6. Pearson correlation's test for the covariates modelled.

The multivariate regression model was then carried out selecting the best combination of the remaining nine variables via stepwise comparison -minimising an Akaike Information Criterion- which allows the evaluation of the relative merit of different models built from the combination of the covariates (Baddeley et al., 2016: 335-336) (Table 2).

[Caption] Table 2. Results of the multivariate regression model. 
FINAL VERSION: Carrero-Pazos, M., Bustelo-Abuín, J., Barbeito-Pose, V., RodríguezRellán, C. (2020). Locational preferences and spatial arrangement in the barrow landscape of Serra do Barbanza (North-western Iberia). Journal of Archaeological Science: Reports 31. https://doi.org/10.1016/i.jasrep.2020.102351

The results of the multivariate regression model rule out the distance to rivers and the topographic prominence index $(500 \mathrm{~m})$ as explanatory variates, as opposed to what could be deduced from the simple observation of the intensity maps. On the contrary, elevation, distance to watershed edges, slope, least cost path density (routes), total viewshed and geology are good predictors $(\mathrm{p}<=0.05)$. Although significant, geology and least cost path density have lower values than the rest of the variables (see Table 2).

With this six-variable environmental model, we created in $R$ Statistics a predicted firstorder intensity surface (Figure 6), which can be used to analyse the second-order interactions in the distribution of mounds.

[Caption] Figure 7. Predicted first-order intensity surface.

\section{Second-order dynamics}

The study of the second-order properties of a point distribution involves considering whether the location of points depends on other points, in what has been called interaction (Nakoinz \& Knitter 2016: 135). When there is no interaction between points, then the point pattern is random (Complete Spatial Randomness).

Following former works (Bevan et al. 2013; Carrero-Pazos et al. 2019), to approach the second order properties of the mounds located in the highlands of Serra do Barbanza, we can consider -in the first instance- a pair correlation function of the megaliths with an envelope of wholly random Monte Carlo Simulations (Figure 8: A).

The observed function shows spatial clustering at local scales up to approximately 1000 $\mathrm{m}$, when the observed pattern may become regular, although the random envelope suggests that such clustering is not significant from $400 \mathrm{~m}$ onwards. Therefore, clustering at local scales (up to $400 \mathrm{~m}$., as shown in figure $8 \mathrm{~A}$ ) is not coincidental, and it may be the result of external or internal variables influencing the distribution of points. The most likely explanation could be the effect of some environmental variables not taken into account in this paper and/or of interaction between sites, such as aggregation processes, which caused tumuli to be built near pre-existing ones -second-order trend(e.g. "tradition", in terms of Villoch Vázquez 2000).

To examine whether this pattern is the result of the preference for a specific landscape or it is a consequence of attraction or repulsion between megalithic monuments, the 
FINAL VERSION: Carrero-Pazos, M., Bustelo-Abuín, J., Barbeito-Pose, V., RodríguezRellán, C. (2020). Locational preferences and spatial arrangement in the barrow landscape of Serra do Barbanza (North-western Iberia). Journal of Archaeological Science: Reports 31. https://doi.org/10.1016/i.jasrep.2020.102351

intensity of first-order factors in the calculation of the pair correlation function was considered. This was done by forcing the random simulations to take into account the spatially inhomogeneous intensities modelled by the predicted intensity surface (shown in figure 7) (Bevan et al. 2013). The results (Figure 8: B) show how the observed data matches fairly well the resulting random envelope suggesting that the point process can be explained by environmental affordances. Therefore, the clustered pattern shown by the mounds in our study area may be the result of a selection of specific types of landscapes. This can be further inspected by comparing the AIC of the random model (1874.368) with that of the environmental one (1692.412). Since the latter is lower, it suggests that the first-order surface is rightly accounting for the spatial pattern of the sites. However, it is still remarkable that the observed function gets close to the upper edge of the envelope at smaller distances, suggesting that there might be some borderline propensity for the sites to be clustered up to distances ca. 150-300 m, a possible lurking trend that cannot be accounted by the influence of environmental variables.

[Caption] Figure 8. Point process models for the study of second-order effects. A: Pair correlation function with a 95\% envelope from wholly random Poisson process. B: Pair correlation function of the observed sites with a $95 \%$ envelope conditioned on the firstorder covariates model. C: Pair correlation function with a 95\% envelope also conditioned on both the first-order covariates and a second-order, area-interaction model $(\mathrm{r}=150 \mathrm{~m})$.

In order to examine this very local -further- clustering, we can explore the comparison of our empirical model with a known theoretical point process model. Following previous works (Bevan et al. 2013), Gibbs point process is perhaps the best choice for our case, since it involves the influence of other points given by an interaction function (Baddeley et al. 2016). As we did in former works (Carrero-Pazos et al. 2019), we use the area-interaction model (Baddeley \& Lieshout 1995), which generates inhibition and clustering patterns with reference to a buffer created for all the points of the distribution. The results (Figure 8: C) suggest that only when considering a strong interaction between the points the observed data fall entirely well over the envelope, being now accounted by first and second-order trends $(\mathrm{AIC}=1359.799)$. The results point out that 
FINAL VERSION: Carrero-Pazos, M., Bustelo-Abuín, J., Barbeito-Pose, V., RodríguezRellán, C. (2020). Locational preferences and spatial arrangement in the barrow landscape of Serra do Barbanza (North-western Iberia). Journal of Archaeological Science: Reports 31. https://doi.org/10.1016/i.jasrep.2020.102351

the resulted environmental variables (elevation, distance to watershed edges, slope, least cost path density (routes), visual prominence and geology) and a very local attraction between points can be used to draw a quite accurate scheme of the distribution of sites in our study area.

\section{Discussion and conclusions}

The analysis of the first-order dynamics has allowed us to ascertain which environmental covariates can predict the current distribution of mounds in the Chans of Barbanza. The defined pattern confirms initial suspicions regarding elevation and slope cut-off as parameters that can define the megalithic distribution in this area (not in the whole Sierra, just in this study area; see Bustelo Abuín 2017 for an extensive work on that sense). This does not mean that elevation, for example, is the unique important variable, as the relation of mounds with watershed borders is clear in this area, something already defended for other areas in Galicia (Carrero-Pazos et al. 2019) and in other European regions, such as south-west England (Bradley 1991b) and Wales (Roese 1980). This is an evidence that megalith builders made quite explicit use of natural features of the landscape (Bradley 1991a: 78) for further functional purposes than the ceremonial use.

From a general point of view, barrows were located, in our study area, in flattened top places, specific locations where mounds can be highly seen from local and long distances, and these areas frequently match the basin edges and natural transit paths. Simultaneously, it is clear that lowlands are not the preferential locations for these sites, mainly for two reasons. The first one is that people probably lived in coastal regions, as research is currently finding evidence of domestic occupation in these areas (Barbeito Pose 2015). Also, behind the decision of choosing upland territories there could be a more functional sense, as the terrain in low areas uses to be less rough for building a megalithic structure.

The location of mounds in areas of wide visibility seems to be an essential factor on the decision to locate the monuments in the landscape, something which is generally accepted for the whole phenomenon (García Sanjuán et al. 2006). However, from a GIS point of view, the question of visibility is more complex, as it is necessary to further conclude if it was the view from the mound, the visibility to the mound or the 
FINAL VERSION: Carrero-Pazos, M., Bustelo-Abuín, J., Barbeito-Pose, V., RodríguezRellán, C. (2020). Locational preferences and spatial arrangement in the barrow landscape of Serra do Barbanza (North-western Iberia). Journal of Archaeological Science: Reports 31. https://doi.org/10.1016/i.jasrep.2020.102351

intervisibility between monuments the locational criteria which determined the spatial value of the architecture (De Reu 2012: 227; Wright et al. 2014).

This is something that happens as well with the relation of megaliths and the movement through the landscape. Pioneering approaches (namely Criado Boado \& Villoch Vázquez 1998, 2000) in Serra do Barbanza defined paths and routes through the Sierra in an ad hoc manner (Fábregas-Valcarce et al. 2018: 89), based on field observations conducted only in the proximity of the sites subjected to analysis. As Fábregas-Valcarce et al. (2018: 89) continue, the resulting path networks connected different clusters of monuments and not parts of the landscape, artificially overestimating the spatial relationship between mounds or other sites (such as petroglyphs) and transit routes. Thus, GIS approaches changed the perspective when analysing the movement through the landscape (e.g. Llobera 2015; Rodríguez Rellan \& Fábregas Valcarce 2019) without take into consideration the sites into the calculus, to check if mounds are truly located at areas of natural transit. And the results are quite convincing. There is a clear relation between mounds and pathways, however, when we analyse the degree of this relation things become less conclusive. Comparatively, the research presented in this paper show that the relation with natural transit seems to be an important locational factor although subordinated to the influence of proximity to watershed edges. This matches, in fact, the research carried out by one of the authors (M.C.) in areas of the South of Galicia where the relation of megaliths and transit routes is not strong as supposed, as there are a high number of mounds that clearly do not relate with potential pathways. On the other hand, in this area megaliths tend to be (more accurately) located in proximity to watershed edges, places that can coincide with natural pathways or not (Carrero-Pazos et al. 2019). As resulted from our work, the proximity to watershed edges accounts for the spatial pattern of mounds (sites located very closed to water basin edges) better than the density of least cost paths (sites located in nodes of natural pathways), which let us to think about the spatial arrangement of sites in terms of some kind of territoriality (Carrero-Pazos et al. 2019).

To sum up, the spatial and visual relation of mounds with pathways is something already noted by former works in this and other areas (Murrieta-Flores 2012; Llobera 2015; Carrero-Pazos 2017; Carrero-Pazos \& Rodríguez Casal 2018a, 2019; Rodríguez Rellán \& Fábregas Valcarce 2019). Further approaches in other areas suggest that a 
FINAL VERSION: Carrero-Pazos, M., Bustelo-Abuín, J., Barbeito-Pose, V., RodríguezRellán, C. (2020). Locational preferences and spatial arrangement in the barrow landscape of Serra do Barbanza (North-western Iberia). Journal of Archaeological Science: Reports 31. https://doi.org/10.1016/i.jasrep.2020.102351

visual relation of megaliths with natural pathways may explain specific visual trends (Murrieta-Flores 2010; Wheatley et al. 2010; Carrero-Pazos 2018b).

As pointed out before, all of this has been also approached for Serra do Barbanza but from a more interpretative sense, through the lens of landscape archaeology, which propose that mounds were specifically located dominating agricultural areas (e.g. Criado Boado et al. 1986: 169), getting as well a territorial meaning by orienting the human movement through the Sierra (Criado Boado \& Villoch Vázquez 2000). Although both explanations are really interesting, the spatial arrangement of the necropoli should be considered on the basis of a wide contrasted dating program, as they probably comprise monuments from different periods (see e. g. the case of Cotogrande - Abad Gallego 1996- or Serra da Aboboreira -Jorge 1982-). Related to that, we have rigorously demonstrated through spatial statistics that there is some influence of pre-existing mounds in the construction of new ones. Although in a context of temporal uncertainty, this means that the presence of monuments in specific areas of the Serra do Barbanza could have "fostered" encourage the erection new ones in the vicinity, something already suggested in the framework of landscape archaeology (Wheatley 1996; Villoch Vázquez 2000) or for other archaeological phenomena, such as Galician rock art (see Rodríguez Rellán \& Fábregas Valcarce 2015).

All that has been said allow us to conclude that the barrow landscape of Serra do Barbanza analysed here should be considered as a landscape of dynamic perceptions (Carrero-Pazos 2017), involving the use and re-use of the same place for constructing cemeteries during several millennia. As stated by Fábregas-Valcarce (et al. 2018: 96), such diversity calls for a qualification of the automatic consideration of these monuments as landmarks intended to been seen, being this true for some barrows but maybe others intended to remain unnoticed.

\section{Acknowledgements}

Prof. A. A. Rodríguez Casal (University of Santiago de Compostela) kindly provided the photographs used in figure 2. The digital elevation model (LiDAR based) was obtained from the Spanish National Cartographic Service (http://centrodedescargas.cnig.es/CentroDescargas/index.jsp), derived from MDT05 CC-BY 4.0 http://www.scne.es/productos.html\#MDT. The geological map was retrieved from 1:50.000 MAGNA National Geological Map (B.O.E. 15/06/2009), 
FINAL VERSION: Carrero-Pazos, M., Bustelo-Abuín, J., Barbeito-Pose, V., RodríguezRellán, C. (2020). Locational preferences and spatial arrangement in the barrow landscape of Serra do Barbanza (North-western Iberia). Journal of Archaeological Science: Reports 31. https://doi.org/10.1016/i.jasrep.2020.102351

IGME - Geological and Mining Institute of Spain (http://info.igme.es/cartografiadigital/geologica/Default.aspx?language=es). This research has been carried out under the I2C Postdoctoral Plan (Mod. A) - Xunta de Galicia Government (MCP). The authors are grateful to the anonymous reviewers for their comments and suggestions.

\section{References}

Abad Gallego, J. C. (1996). El fenómeno megalítico y su presencia en la comarca de Vigo. Boletín del Instituto de Estudios Vigueses 2, 129-145.

Baddeley, A. J. \& M. N. N. Van Lieshout (1995). Area-Interaction point processes. Annals of the Institute of Statistical Mathematics 47, 601-619.

Barbeito Pose, V., Fábregas Valcarce, R., Rodríguez Rellán, C., Fariña Costa, A., Paz Camaño, A., López Taboada M. ${ }^{a}$ de los Á., Suárez Piñeiro, A. M. ${ }^{a}$, Abascal Palazón, J. M., Fernández Suárez, G. F., Casado González, G., Vázquez Martínez, A., Mariño Calvo, M. V. (2018). Do planalto ás terras baixas: novas achegas á ocupación da península do Barbanza dende a Prehistoria ata o Medievo. Gallaecia 37, 1-38.

Bello Diéguez, J. M. a, Criado Boado, F. \& J. M. Vázquez Varela (1982a). Aproximación a un modelo económico-social del megalitismo del noroeste peninsular. Brigantium 3, 33-39.

Bello Diéguez, J. M. a, Criado Boado, F. \& J. M. Vázquez Varela (1982b). Megalitismo y medio físico en el Noroeste de la Península Ibérica: Estado de la cuestión y perspectivas. Zephyrus XXXIV-XXXV, 109-118.

Bello Diéguez, J. M. a, Criado Boado, F. \& J. M. Vázquez Varela (1987). La cultura megalítica de la provincia de la Coruña y sus relaciones con el marco natural: implicaciones socio-económicas. A Coruña: Excma. Diputación provincial de A Coruña.

Bevan, A. (2012). Spatial methods for analysing large-scale artefact inventories. Antiquity 86 (443), 493-506.

Bevan, A., Crema, E., Xiuzhen, L. \& A. Palmisano (2013). Intensities, interactions and uncertainties: some new approaches to archaeological distributions. In Bevan, A., Lake, M. (Ed.). Computational approaches to archaeological landscapes (pp. 27-52). Walnut Creek, California: Left Coast Press. 
FINAL VERSION: Carrero-Pazos, M., Bustelo-Abuín, J., Barbeito-Pose, V., RodríguezRellán, C. (2020). Locational preferences and spatial arrangement in the barrow landscape of Serra do Barbanza (North-western Iberia). Journal of Archaeological Science: Reports 31. https://doi.org/10.1016/i.jasrep.2020.102351

Boehner, J., Koethe, R. Conrad, O., Gross, J., Ringeler, A. \& T. Selige (2002). Soil Regionalisation by Means of Terrain Analysis and Process Parameterisation. In E. Micheli, F. Nachtergaele, L. Montanarella, Soil Classification 2001 (pp. 213-222). European Soil Bureau, Research Report No. 7, EUR 20398 EN, Luxembourg.

Bourgeois, Q., 2013. Monuments on the Horizon. The Formation of the Barrow Landscape throughout the 3rd and 2nd Millennium BC. Leiden: Sidestone Press.

Bradley, R. (1991a). Rock art and the perception of landscape. Cambridge Archaeological Journal 1, 77-101.

Bradley, R. (1991b). Monuments and places. In P. Garwood, D. Jennings, R. Skeates \& J. Thoms Sacred and Profane. Oxford: Oxford University Committee for Archaeology. Brughmans, T., van Garderen, M. \& M. Gillings (2018). Introducing visual neighbourhood configurations for total viewsheds. Journal of Archaeological Science 96, 14-25. http://dx.doi.org/10.1016/j.jas.2018.05.006

Bustelo Abuín, J., Rodríguez Rellán, C., Fábregas Valcarce, R. \& V. Barbeito Pose (2017). Alén da Serra. O fenómeno tumular na Península do Barbanza a través dos SIX e a estatística espacial. Gallecia 37, 53-72.

Carrero-Pazos, M. (2017). The Megalithic Phenomenon in Galicia. Contributions from Geographic Information Systems and Spatial Statistics to the Study of Site Location Patterns. PhD Thesis. University of Santiago de Compostela: Santiago de Compostela. http://hdl.handle.net/10347/15823

Carrero-Pazos, M. (2018a). Beyond the scale. Building formal approaches for the study of spatial patterns in Galician moundscapes (NW Iberian Peninsula). Journal of Archaeological Science: Reports 19, 538-551.

Carrero-Pazos, M. (2018b). Modelando dinámicas de movilidad y visibilidad en los paisajes megalíticos gallegos. El caso del Monte de Santa Mariña y su entorno (Comarca de Sarria, Lugo). Trabajos de Prehistoria 75(2), 287-306. https://doi.org/10.3989/tp.2018.12216

Carrero-Pazos, M. \& A. A. Rodríguez Casal (2015). Definiendo patrones de emplazamiento del Megalitismo gallego: la necrópolis del Monte de Santa Mariña como modelo. Sémata. Ciencias Sociais e Humanidades 27, 299-321.

Carrero-Pazos, M. \& A. A. Rodríguez Casal (2019). General and local spatial trends in Galician megalithic landscapes. In J. Müller, M. Hinz, M. Wunderlich, Megaliths, 
FINAL VERSION: Carrero-Pazos, M., Bustelo-Abuín, J., Barbeito-Pose, V., RodríguezRellán, C. (2020). Locational preferences and spatial arrangement in the barrow landscape of Serra do Barbanza (North-western Iberia). Journal of Archaeological Science: Reports 31. https://doi.org/10.1016/i.jasrep.2020.102351

Societies, Landscapes. Early monumentality and social differentiation in Neolithic Europe (pp. 641-665). Habelt: Bonn.

Carrero-Pazos, M., Bevan, A. \& M. Lake (2019). The Spatial Structure of Galician Megalithic Landscapes (NW Iberia): A Case Study from the Monte Penide Region. Journal of Archaeological Science 108. https://doi.org/10.1016/j.jas.2019.05.004

Castillo López, Á. d. (1927). Un depósito de hachas del bronce de talón. Boletín de la Real academia Galega 17 (194), 33-42.

Conolly, J., Lake, M. (2006). Geographical Information Systems in Archaeology (Cambridge Manuals in Archaeology). Cambridge University Press: Cambridge. doi:10.1017/CBO9780511807459

Criado Boado, F. (1980). Catalogación de mámoas en los municipios de Curtis, Sobrado y tierras adyacentes. Brigantium 1, 13-40.

Criado Boado, F. (1984a). El tercer factor o la lógica oculta del emplazamiento de los túmulos megalíticos gallegos. Cuadernos de Estudios Gallegos 35, 7-18.

Criado Boado, F. (1984b). Prospecciones de túmulos megalíticos en la provincia de A Coruña (Campaña de 1984): Serra do Bocelo. Memoria Inédita. Universidade de Santiago de Compostela-Xunta de Galicia: Santiago de Compostela.

Criado Boado, F. (1988a). Contribución al estudio de las relaciones entre las comunidades megalíticas del noroeste peninsular y su medio natural: implicaciones socio-económicas. Unpublished PhD Thesis. Universidade de Santiago de Compostela: Santiago de Compostela.

Criado Boado, F. (1988b). Mámoas y rozas: panorámica general sobre la distribución de los túmulos megalíticos gallegos. Trabalhos de Antropologia e Etnologia 28 (fasc. 1-2), 151-160.

Criado Boado, F. \& M. Grajal Blanco (1981). Relación entre la distribución de mámoas y el medio físico de la zona de Sobrado-Curtis. Brigantium 2, 7-26.

Criado Boado, F., Aira Rodríguez, M. ${ }^{\text {a }}$ J. \& F. Díaz Fierros Viqueira (1986). La construcción del paisaje: Megalitismo y ecología. Sierra de Barbanza. Xunta de Galicia/Consellería de Educación e Cultura. Dirección Xeral de Patrimonio Artístico e Monumental: Santiago de Compostela.

Criado Boado, F., Bonilla Rodríguez, A., Cerqueiro Landín, D., González Méndez, M., Méndez Fernández, F. \& R. Penedo Romero (1988). Proyecto Bocelo-Furelos: 
FINAL VERSION: Carrero-Pazos, M., Bustelo-Abuín, J., Barbeito-Pose, V., RodríguezRellán, C. (2020). Locational preferences and spatial arrangement in the barrow landscape of Serra do Barbanza (North-western Iberia). Journal of Archaeological Science: Reports 31. https://doi.org/10.1016/i.jasrep.2020.102351

arqueología del paisaje y prospección intensiva en Galicia. Trabalhos de Antropologia e Etnologia 28 (fasc. 1-2), 241-250.

Criado Boado, F. \& J. Vaquero Lastres (1991). El fenómeno megalítico y tumular: formas diversas de pasado monumental. In F. Criado Boado (Ed.), Arqueología del paisaje. El área Bocelo-Furelos entre los tiempos paleolíticos y medievales (pp. 129146). Xunta de Galicia: A Coruña.

Criado Boado, F. \& V. Villoch Vázquez (2000). Monumentalising Landscape: From Present Perception to Past Meaning of Galician Megalithism (North-West Iberian Peninsula). European Journal of Archaeology 3 (2), 188-216.

Criado-Boado, F., Vuelta-Santín, R. (2017). Rocking Barbanza. Una representación performativa de la organización espacial del paisaje megalítico en la Sierra de Barbanza (Galicia, España). http://hdl.handle.net/10261/154985

Díaz Sanjurjo, M. (1904). Los caminos antiguos y el itinerario n ${ }^{\circ} 18$ de Antonino en la provincia de Orense. Boletín de la Comisión de Monumentos Históricos y Artísticos de Orense 2, 37-43.

De Reu, J. (2012). Land of the dead. A comprehensive study of the Bronze Age burial landscape in north-western Belgium. PhD Thesis. Ghent: Ghent University, Department of Archaeology.

De Reu, J., Bourgeois, J., De Smedt, P., Zwertvaegher, A., Antrop, M., Bats, M., P. Crombé (2011). Measuring the relative topographic position of archaeological sites in the landscape, a case study on the Bronze Age barrows in northwest Belgium. Journal of Archaeological Science 38 (12), 3435-3446. Doi: 10.1016/j.jas.2011.08.005

Eguileta Franco, J. M. (1999). A Baixa Limia na Prehistoria Recente. Arqueoloxía dunha Paisaxe na Galicia interior. Excma. Diputación Provincial de Ourense: Ourense. Fábrega-Álvarez, P. (2004). Poblamiento y territorio de la cultura castreña en la comarca de Ortegal. Laboratorio de Patrimonio, Paleoambiente e Paisaxe. Universidade de Santiago de Compostela: Santiago de Compostela.

Fábrega-Álvarez, P. \& C. Parcero-Oubiña (2007). Proposal for an archaeological analysis of pathways and movement. Archeologia e Calcolatori 18, 121-140.

Fábrega-Álvarez, P., \& C. Parcero-Oubiña (2019). Now you see me. An assessment of the visual recognition and control of individuals in archaeological landscapes. Journal of Archaeological Science 104, 56-74. 
FINAL VERSION: Carrero-Pazos, M., Bustelo-Abuín, J., Barbeito-Pose, V., RodríguezRellán, C. (2020). Locational preferences and spatial arrangement in the barrow landscape of Serra do Barbanza (North-western Iberia). Journal of Archaeological Science: Reports 31. https://doi.org/10.1016/i.jasrep.2020.102351

Fábregas Valcarce, R. \& X. I. Vilaseco Vázquez (2002). O Megalitismo na comarca de Deza. Un proxecto para a conservación do patrimonio arqueolóxico inmoble. Descubrindo. Anuario de estudios e investigación de Deza 4, 107-126.

Fábregas Valcarce, R., Gómez Fernández, A., Rodríguez Rellán, C. \& X. I. Vilaseco Vázquez (2003). Estudios en torno ao Megalitismo da comarca do Deza. Primeiros resultados. Descubrindo. Anuario de estudios e investigación de Deza 5, 91-112.

Fábregas Valcarce, R., Gómez Fernández, A., Rodríguez Rellán, C. \& X. I. Vilaseco Vázquez (2004). O Megalitismo da Comarca do Deza. Resultados e perspectivas. Descubrindo. Anuario de estudios e investigación de Deza 6, 41-53.

Fábregas Valcarce, R. \& C. Rodríguez Rellán (2012). A arte rupestre no norte do Barbanza. Andavira Editora: Santiago de Compostela.

Fábregas Valcarce, R., Rodríguez-Rellán, C., Bustelo Abuín, J. \& V. Barbeito Pose (2018). Building up the land: a new appraisal to the megalithic phenomenon in the Barbanza peninsula (Galicia, NW Spain). In J.C. Senna-Martínez, M. Diniz \& A. F. Carvalho (eds) De Gibraltar aos Pirenéus. Megalitismo, vida e morte na Fachada Atlântica Peninsular (pp. 85-98). Fundaçâo Lapa do Lobo (Nelas): Lapa do Lobo.

Fernández Cacho, S., Rodrigo Cámara, J. M. (2003). MAPA. Modelo Andaluz de Predicción Arqueológica (e-ph cuadernos, 1). Consejería de Cultura: Sevilla.

Filgueiras Rey, A. I., T. Rodríguez Fernández (1994). Túmulos y petroglifos. La construcción de un espacio funerario. Aproximación a sus implicaciones simbólicas. Estudio en la Galicia centro-oriental: Samos y Sarria. Espacio, Tiempo y Forma (Serie I, Prehistoria y Arqueología) 7, 211-253.

García Sanjuán, L., Metcalfe-Wood, S., Rivera Jiménez, T. \& D. W. Wheatley (2006). Análisis de pautas de visibilidad en la distribución de monumentos megalíticos de Sierra Morena occidental. In I. Grau Mira (Ed.), La Aplicación de los SIG en la Arqueología del Paisaje (pp. 181-200). Universidad de Alicante: Alicante.

Gómez Vila, J. (2005). Caminos y túmulos: aproximación al estudio de los caminos megalíticos en el noroeste peninsular. In P. Arias Cabal, R. Ontañón Peredo \& C. García Moncó (Eds.), Actas del III Congreso del Neolítico en la Península Ibérica (Santander, 2003) (pp. 405-412). Universidad de Cantabria: Santander.

Guisan, A., Weiss, S. B. \& A. D. Weiss (1999). GLM versus CCA spatial modeling of plant species distribution. Plant Ecology 143, 107-122. 
FINAL VERSION: Carrero-Pazos, M., Bustelo-Abuín, J., Barbeito-Pose, V., RodríguezRellán, C. (2020). Locational preferences and spatial arrangement in the barrow landscape of Serra do Barbanza (North-western Iberia). Journal of Archaeological Science: Reports 31. https://doi.org/10.1016/i.jasrep.2020.102351

Guitián Rivera, L. (1978). El medio físico de la península de Barbanza. In Miscelánea de Geografia de Galicia en homenaje a Otero Pedrayo (pp. 109-130). Universidade de Santiago de Compostela: Santiago de Compostela.

Jorge, V. O. (1982). Megalitismo do norte de Portugal: o distrito do porto. Os monumentos e a sua problemática no contexto europeu. Universidade do Porto: Porto.

Jorge, V. O. (1991). Necrópole pré-histórica da Aboboreira (Distrito do Porto). Uma hipótese de diacronía. En M. C. Rodriguez Lopes (Ed.), Homenagem a J. R. dos Santos Júnios (Vol. I, pp. 205-213). Instituto de Investigaçao Científica Tropical: Lisboa.

Judge, W. J., Sebastian, L. (Eds.) (1988). Quantifying the Present and Predicting the Past: Theory, Method and Application of Archaeological Preditive Modeling. Washington: US Bureau of Land.

Knitter, D. \& O. Nakoinz (2018). Point Pattern Analysis as Tool for Digital Geoarchaeology: A Case Study of Megalithic Graves in Schleswig-Holstein, Germany. In C. Siart, M. Forbriger \& O. Bubenzer (Ed.). Digital Geoarchaeology. New Techniques for Interdisciplinary Human-Environmental Research (pp. 45-64). Springer: Switzerland.

Kohler, T. A., Parker, S. C. (1986). Predictive models for archaeological resource location. In Schiffer, M. B. Advances in Archaeological Method and Theory (397-452). Academic Press: New York.

Kvamme, K. L. (1983). Computer processing techniques for regional modeling of archaeological site locations. Advances in Computer Archaeology 1, 26-52.

Kvamme, K. L. (1990). The fundamental principles and practice of predictive archaeological modeling. In A. Voorrips (Ed.), Mathematics and Information Science in Archaeology: A Flexible Framework (Vol. Studies in Modern Archaeology 3) (257295). Bonn: Holos-Verlag.

Lake, M. \& P. Woodman (2003). Visibility studies in archaeology: a review and case study. Environment and Planning B: Planning and Design 30, 689-707.

Lennard-Jones, J. E. (1924). On the determination of molecular fields. Proceedings of the Royal Society A 106, 463-477.

Leisner, G. (1938). Verbreitung und Typologie der Galizisch-Nordportugiesischen Megalithgräber. J. B. Lindin: München.

Llobera, M. (2001). Building past landscape perception with GIS: understanding topographic prominence. Journal of Archaeological Science 28, 1005-1014. 
FINAL VERSION: Carrero-Pazos, M., Bustelo-Abuín, J., Barbeito-Pose, V., RodríguezRellán, C. (2020). Locational preferences and spatial arrangement in the barrow landscape of Serra do Barbanza (North-western Iberia). Journal of Archaeological Science: Reports 31. https://doi.org/10.1016/i.jasrep.2020.102351

Llobera, M. (2003). Extending GIS-based visual analysis: The concept of "visualscapes". International Journal of Geographical Information Science 17, 25-48.

Llobera, M., Wheatley, D., Steele, J., Cox, S. \& O. Parchment (2010). Calculating the Inherent Visual Structure of a Landscape ("Total Viewshed") Using High-Throughput Computing. In Nicolucci, F., S. Hermon (Eds.), Beyond the Artefact. Digital Interpretation of the Past. Proceedings of CAA 2004 (Prato, 13-17 April 2004) (pp. 146-151). Archaeolingua: Budapest.

Llobera, M. (2015). Working the Digital: Some thoughts from Landscape Archaeology. In Chapman, R., A. Wylie (Eds.). Material Evidence: Learning from Archaeological Practice (pp. 173-188). Routledge: Abingdon.

López Cuevillas, F. (1925). As mámoas do Concello de Lobeira. Boletín de la Real Academia Gallega XV, 25-39.

López Cuevillas, F. (1933). Prehistoria de Melide. In R. Otero Pedrayo (Ed.), Terra de Melide (Vol. Cap. I). Seminario de Estudos Galegos: Santiago de Compostela.

López Cuevillas, F. (1973, orig. 1952). A edade megalítica. In R. Otero Pedrayo (dir.), Historia de Galiza, T. III (pp. 43-122). Editorial Nós: Buenos Aires.

Maciñeira, F. (1935). La distribución de las estaciones prehistóricas ortegaleses y sus características. Boletín de la Real academia Galega 259, 169-181.

Maciñeira, F. (1943-1944). Túmulos prehistóricos. Inventario descriptivo de los 286 túmulos prehistóricos hasta ahora descubiertos en la avanzada comarca del cabo Ortegal. Boletín de la Real Academia Gallega 23-24, 15-34.

Méndez Fernández, F. (1998). Definición y análisis de poblados de la Edad del Bronce en Galicia. En R. Fábregas Valcarce (Ed.), A Idade do Bronce en Galicia: novas perspectivas (Vol. 77, pp. 153-190). Cadernos do Seminario de Sargadelos: A Coruña.

Murrieta-Flores, P. (2012). Understanding movement during late prehistory through spatial technologies: the role of natural areas of transit in south-western Iberia. Trabajos de Prehistoria 69, 114-133.

Murrieta-Flores, P. A. (2010). Travelling in a prehistoric landscape: Exploring the influences that shape human movement. In B. Frischer, J. Weeb Crawford \& D. Koller. Making History Interactive. Computer applications and quantitative methods in archaeology (CAA2009). Proceedings of the 37th international conference, Williamsburg, Virginia, USA, March 22-26, 2009 (pp. 249-267). Oxford: Archaeopress. 
FINAL VERSION: Carrero-Pazos, M., Bustelo-Abuín, J., Barbeito-Pose, V., RodríguezRellán, C. (2020). Locational preferences and spatial arrangement in the barrow landscape of Serra do Barbanza (North-western Iberia). Journal of Archaeological Science: Reports 31. https://doi.org/10.1016/i.jasrep.2020.102351

Nakoinz, O. \& D. Knitter (2016). Modelling Human Behaviour in Landscapes. Basic Concepts and Modelling Elements. Springer: Switzerland.

Nonn, H. (1966). Les Régions cotières de la Galice (Espagne): Étude géomorphologique. Centre National de la Recherche Scientifique, Université de Strasbourg: Strasbourg.

Parcero-Oubiña, C. (2000). La construcción del paisaje social en la Edad del Hierro del noroeste ibérico. Tesis Doctoral. Universidade de Santiago de Compostela: Santiago de Compostela.

Parcero-Oubiña, C. \& Fábrega-Álvarez, P. (2006). Diseño metodológico para el análisis locacional de asentamientos a través de un SIG de base raster. In I. Grau Mira (Ed.), La aplicación de los SIG en la Arqueología del Paisaje (pp. 69-91). Servicio de Publicaciones Universidad de Alicante: Alicante.

R Development Core Team (2008). R: A language and environment for statistical computing. R Foundation for Statistical Computing, Vienna, Austria. ISBN 3-90005107-0, URL http://www.R-project.org

Roese, H. (1980). Some aspects of topographical location of Neolithic and Bronze Age monuments in Wales, 1: menhirs. Bulletin of the Board of Celtic Studies 28, 645-655.

Rodríguez Álvarez, E. (2012). Os petroglifos do Barbanza dende unha perspectiva espacial. In R. Fábregas Valcarce \& C. Rodríguez Rellán (Eds.). A arte rupestre no norte do Barbanza (pp. 121-134). Andavira Editora: Santiago de Compostela.

Rodríguez Casal, A. A. (1990). O Megalitismo. A primeira arquitectura monumental de Galicia. Universidade de Santiago de Compostela: Santiago de Compostela.

Rodríguez Casal, A. A. (1997). O Neolítico Atlántico e as orixes do Megalitismo. Actas do Coloquio Internacional (Santiago de Compostela, 1996). Universidade de Santiago de Compostela: Santiago de Compostela.

Rodríguez Casal, A. A., Gómez Nistal, C. \& E. Romaní Fariña (1998). El Fenómeno tumular y megalítico en las tierras de Sarria-O Incio (Lugo). Gallaecia 17, 69-105.

Rodríguez Rellán, C. \& R. Fábregas Valcarce (2015). Arte rupestre galaica: unha achega dende a estatística espacial e os SIX. Sémata, Ciencias Sociais e Humanidade 27, 323-348.

Rodríguez Rellán, C. \& R. Fábregas Valcarcr (2019). Monuments on the move. Assessing megalith's interaction with NW Iberian landscapes. In J. Müller, M. Hinz \& 
FINAL VERSION: Carrero-Pazos, M., Bustelo-Abuín, J., Barbeito-Pose, V., RodríguezRellán, C. (2020). Locational preferences and spatial arrangement in the barrow landscape of Serra do Barbanza (North-western Iberia). Journal of Archaeological Science: Reports 31. https://doi.org/10.1016/i.jasrep.2020.102351

M. Wunderlich. Megaliths, Societies, Landscapes. Early monumentality and social differentiation in Neolithic Europe (pp. 621-639). Habelt: Bonn.

Santos Estévez, M. (2008). Petroglifos y paisaje social en la prehistoria reciente del noroeste de la Península Ibérica (TAPA, Vol. 38). Instituto de Estudos Galego Padre Sarmiento. CSIC: Santiago de Compostela.

Santos Estévez, M., Parcero Oubiña, C. \& F. Criado Boado (1997). De la arqueología simbólica del paisaje a la arqueología de los paisajes sagrados. Trabajos de Prehistoria 54 (2), 61-80.

Taylor, C (1984). Village and Farmstead: A History of Rural Settlement in England. George Philip: London.

Vaquero Lastres, J. (1990). Ríos y tumbas. Sobre el emplazamiento de túmulos en el NW peninsular. Trabalhos de Antropologia e Etnologia XXX (1-4), 151-173.

Vaquero Lastres, J. (1991-1992). Del análisis del emplazamiento al estudio de la distribución de túmulos en el NW. Brigantium 7, 151-176.

Vaquero Lastres, J. (1993-1994). Galiñeiro, paso de lobos, novios y héroes. Sobre el emplazamiento de los túmulos del Noroeste. Cuadernos de Estudios Gallegos XLI (106), 11-39.

Villoch Vázquez, V. (2000). La configuración del espacio entre las sociedades constructoras de túmulos en Galicia: estudios de emplazamiento tumular. Universidade de Santiago de Compostela: Santiago de Compostela.

Villoch Vázquez, V. (1995). Monumentos y petroglifos: la construcción del espacio en las sociedades constructoras de túmulos del noroeste peninsular. Trabajos de Prehistoria 52 (1), 39-55.

Villoch Vázquez, V. (1998). Un nuevo menhir en Cristal. Gallaecia 17, 107-120.

Weiss, A. (2001). Topographic position and landforms analysis. ESRI User Conference, San Diego. Poster presentation.

Westcott, K. L., Brandon, R. J. (Eds.) (2000). Practical Applications of GIS for Archaeologists: A Predictive Modeling Kit. London: Taylor and Francis.

Wheatley, D. (1996). The use of GIS to understand regional variation in Neolithic Wessex. In H. D. G. Maschner (ed.). New Methods, Old Problems: Geographic Information Systems in Modern Archaeological Research (75-103). CAI Occasional Paper 23. Carbondale: Illinois. 
FINAL VERSION: Carrero-Pazos, M., Bustelo-Abuín, J., Barbeito-Pose, V., RodríguezRellán, C. (2020). Locational preferences and spatial arrangement in the barrow landscape of Serra do Barbanza (North-western Iberia). Journal of Archaeological Science: Reports 31. https://doi.org/10.1016/j.jasrep.2020.102351

Wheatley, D. W., García Sanjuán, L., Murrieta Flores, P. \& J. Márquez Pérez (2010).

The megalithic phenomenon in Southern Spain: Approaching the landscape dimension.

Oxford Journal of Archaeology 29 (4), 387-405.

White, D. A. \& S. B. Barber (2012). Geospatial modelling of pedestrian transportation networks: a case study from pre-Columbian Oaxaca. Journal of Archaeological Science 39, 2684-2696.

Whitle, T. G., Moore, G., Goel, G. \& D. Jackson (2010). Beyond the marsh: settlement choice, perception and spatial decision-making on the Georgia coastal plain. In B. Frischer, J. Crawford \& D. Kollers (Eds.), CAA 2009. Making history interactive. Computer applications and quantitative methods in archaeology. Proceedings of the $37^{\text {th }}$ conference, Williamsburg, VA, USA (pp. 380-390). Archaeopress: Oxford.

Wilson, J. P. \& J. C. Gallant (2000). Terrain Analysis: Principles and Applications. John Wiley and Sons: New York.

Wright, D. K., MacEachern, S. \& J. Lee (2014). Analysis of Feature Intervisibility and Cumulative Visibility Using GIS, Bayesian and Spatial Statistics: A Study from the Mandara Mountains, Northern Cameroon. PLoS ONE 9 (11), e112191. doi:10.1371/journal.pone.011219 


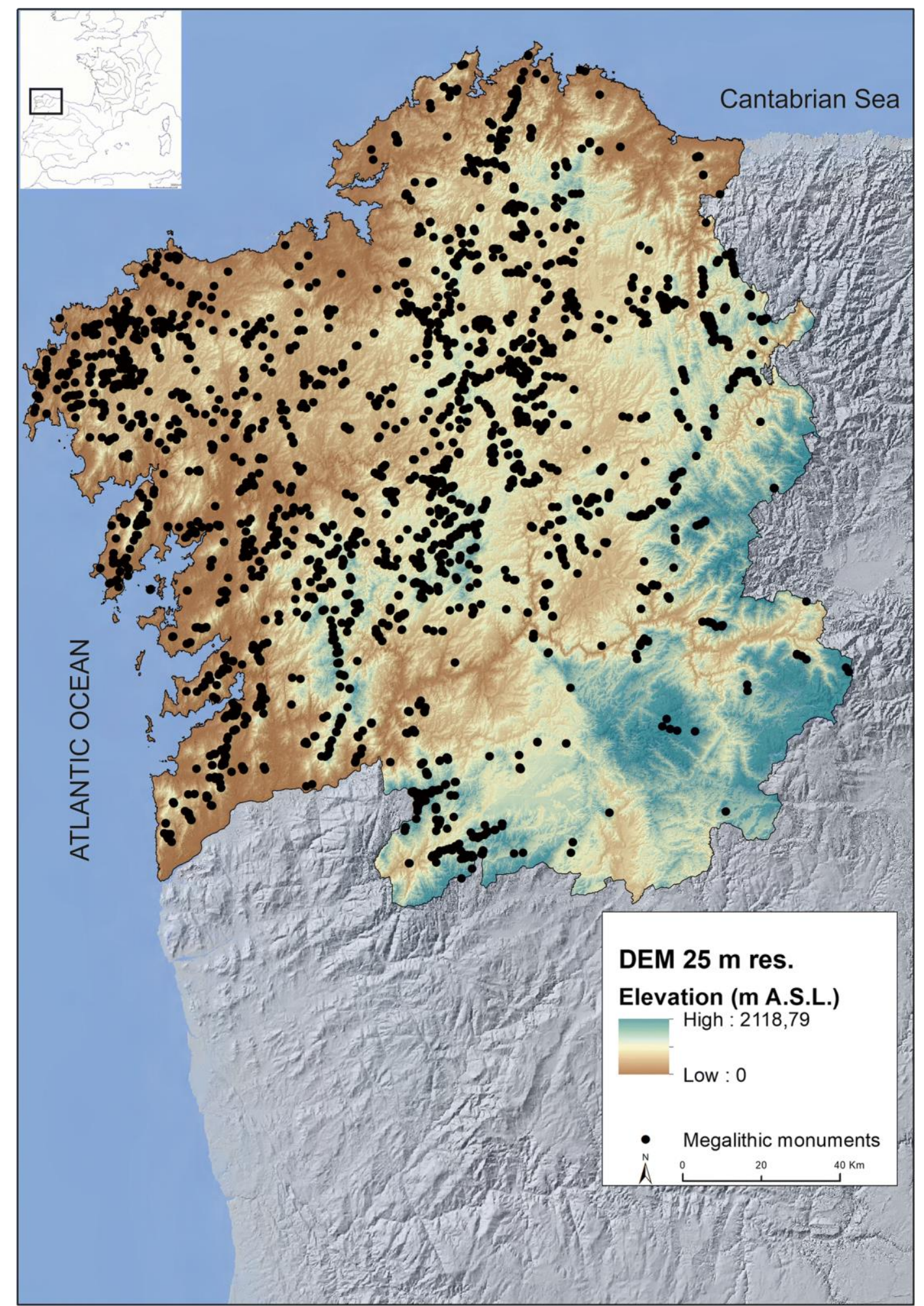

Figure 1. Current distribution of megalithic monuments in Galicia, NW Spain (University of Santiago de Compostela, GEPN-AAT). 

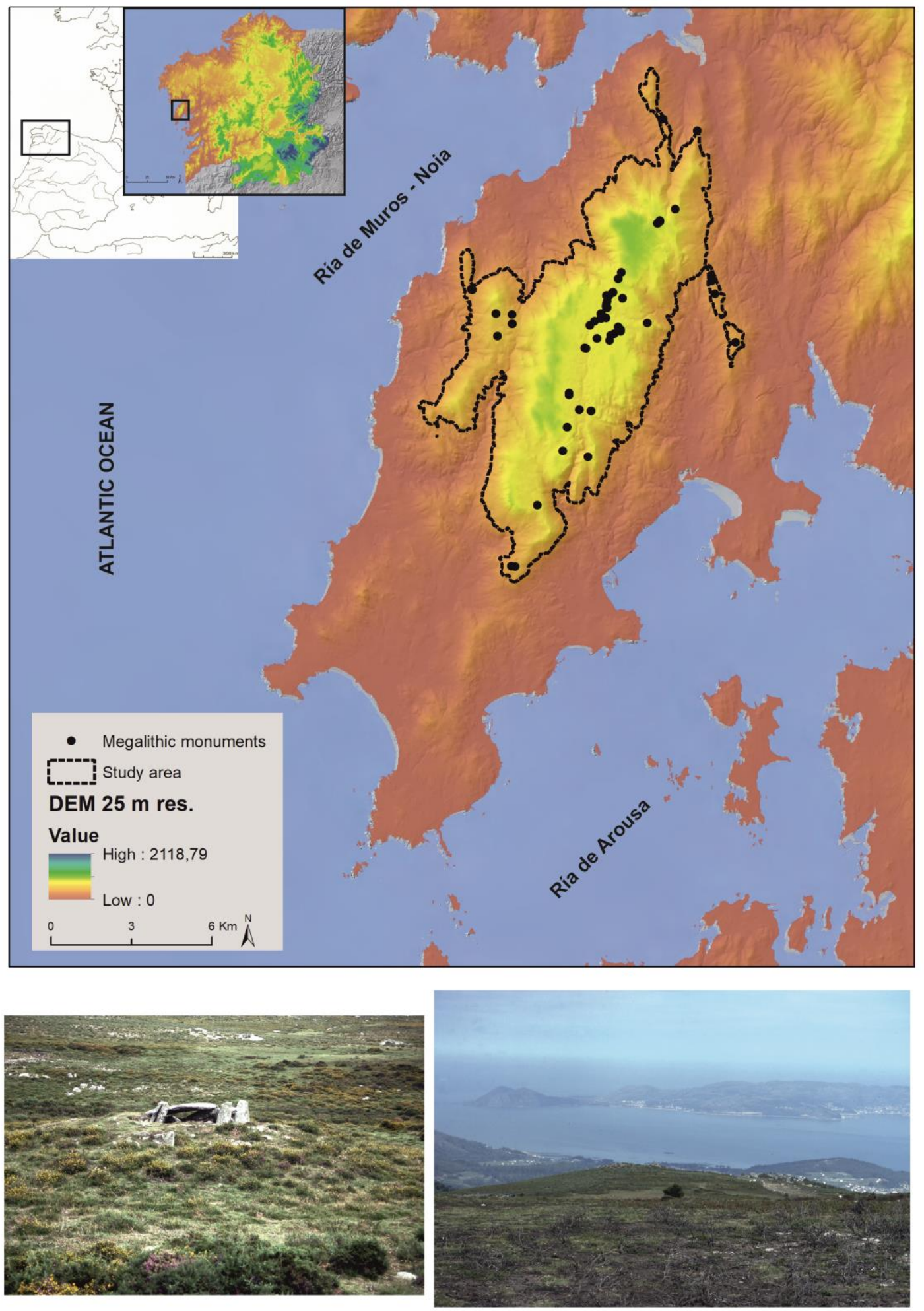

Figure 2. Above: Selected study area, the highlands of Sierra de Barbanza (above 200 meters high). Below: the megalith of Arca da Barbanza, and a view from the Sierra towards the Ría de Muros-Noia (NW). 


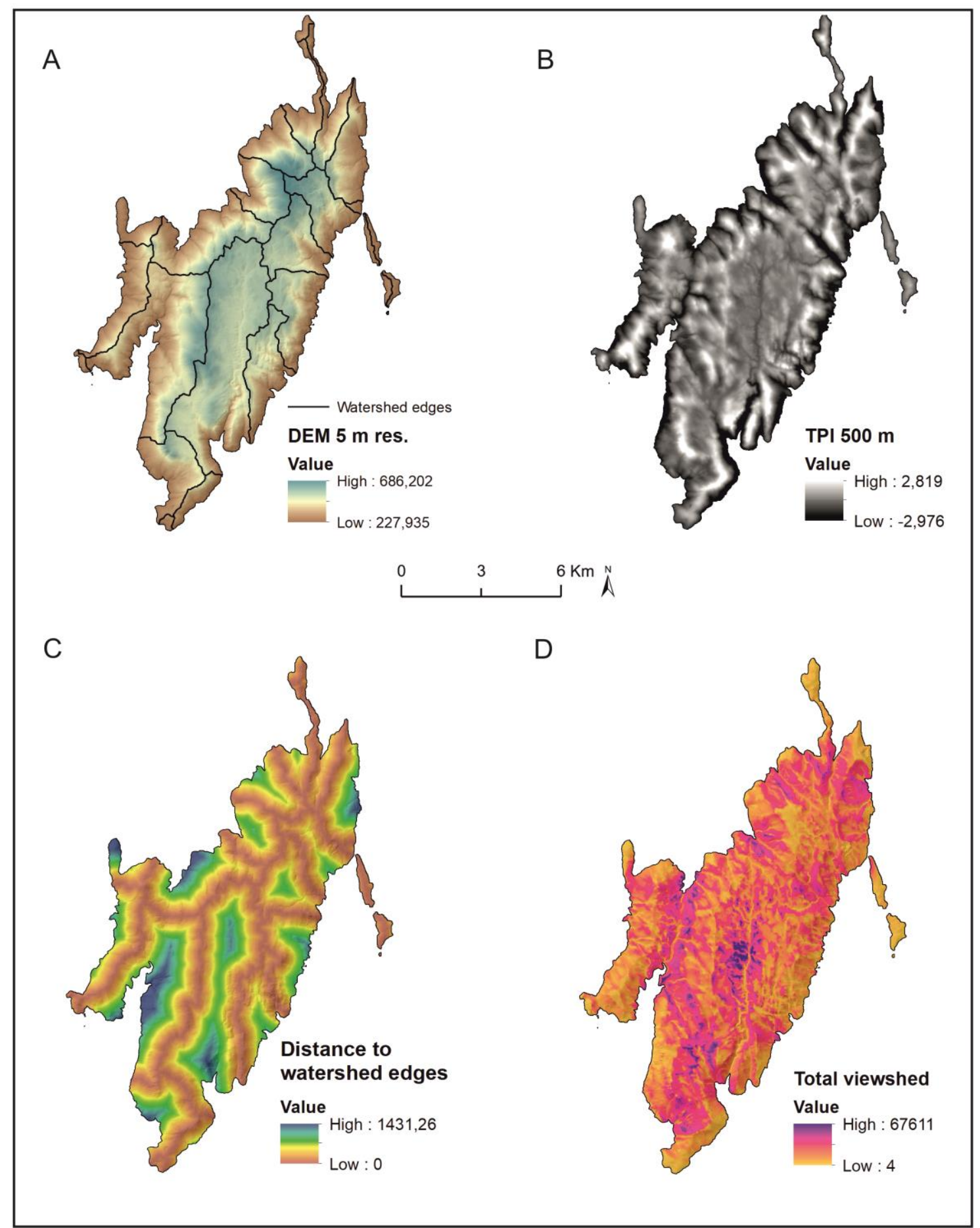

Figure 3. Some of the covariates used in first-order locational modelling. A: Elevation, with watershed edges. B: Topographic prominence at large scale $(500 \mathrm{~m})$. C: Distance to watershed edges (meters). D: Total viewshed. 

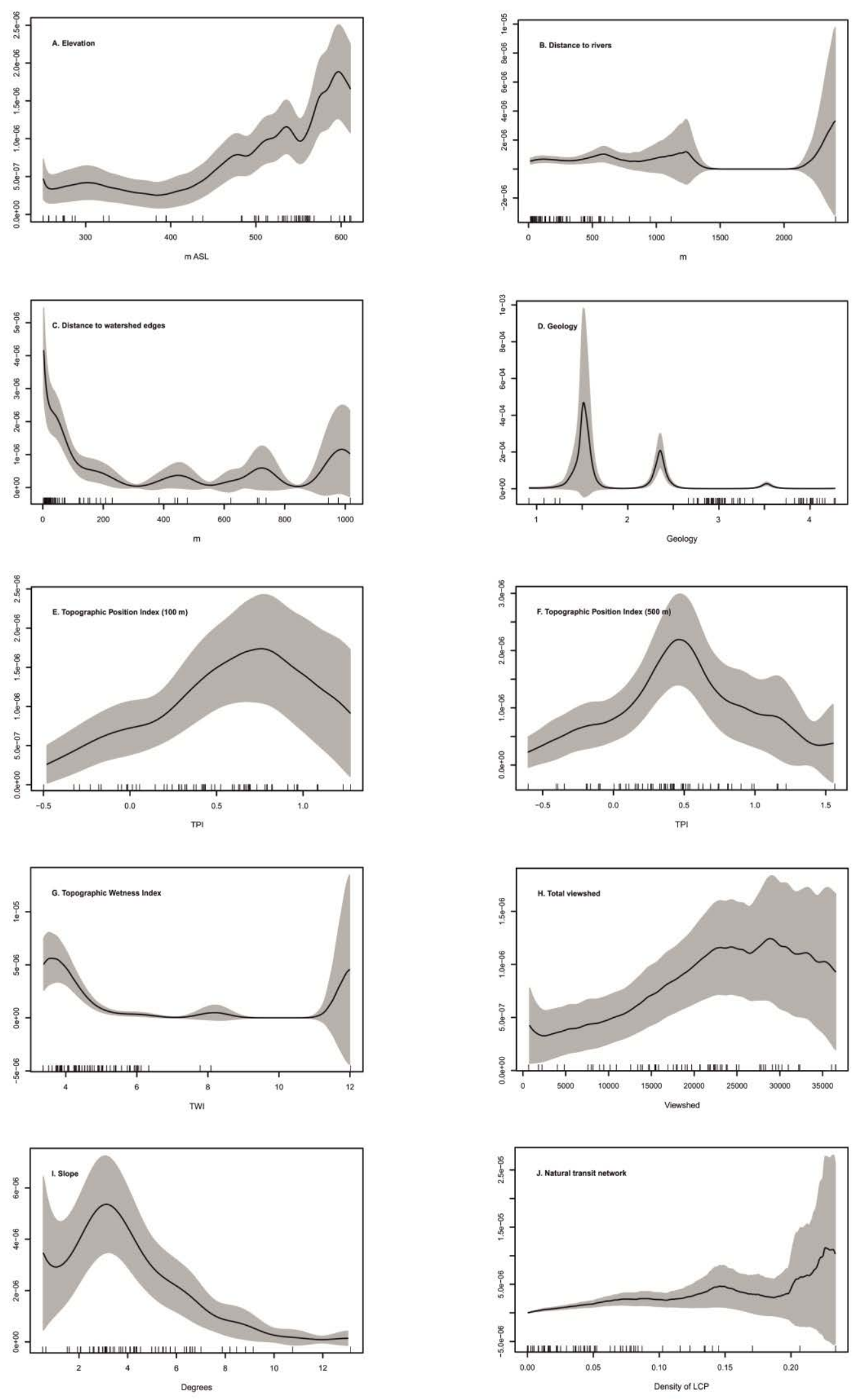

Figure 4. Intensity as an estimated function giving mound density as a function of the different covariates (solid lines show function estimate while grey shading is pointwise 95\% confidence band). 


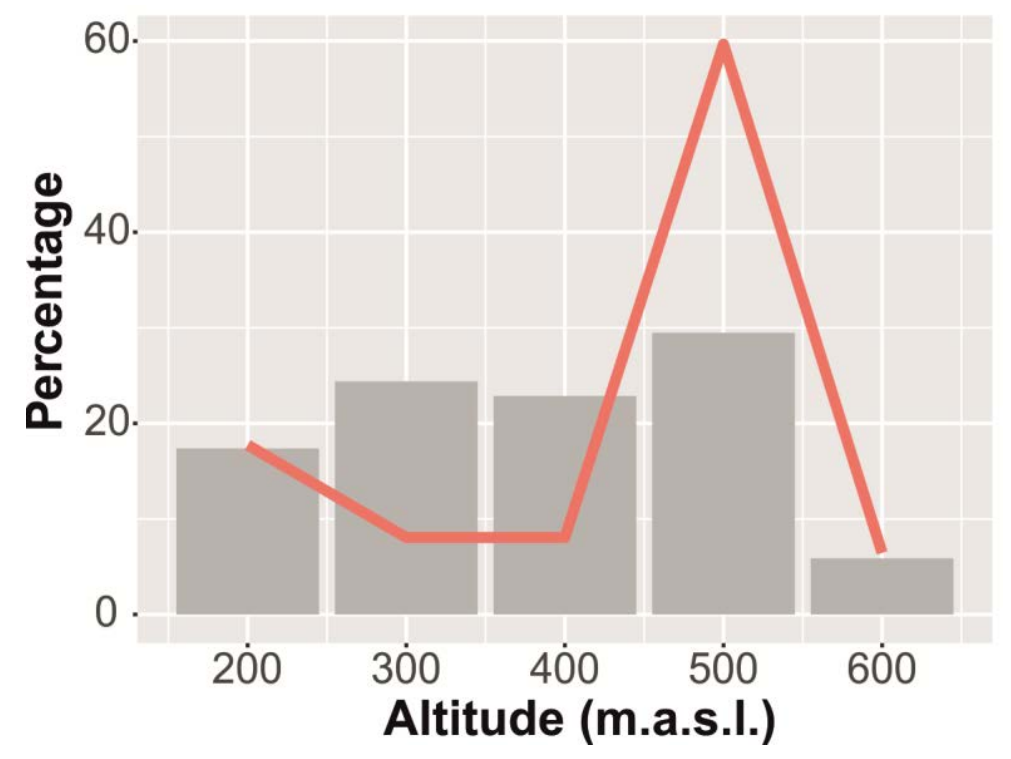

Figure 5. Altitudinal distribution of mounds (line) compared to that of the terrain in the study area (bars).

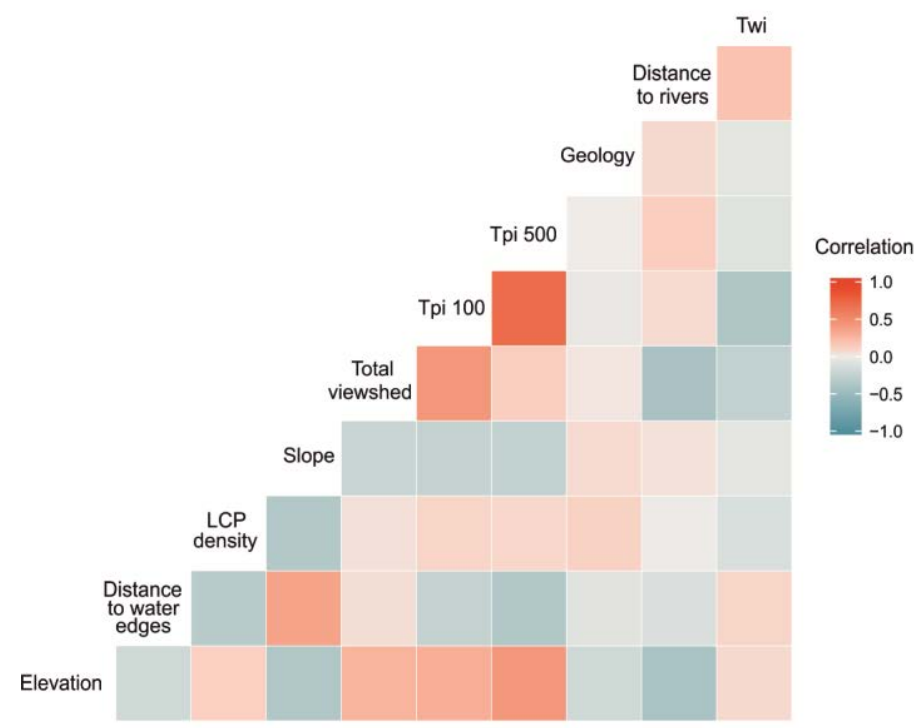

Figure 6. Pearson correlation's test for the covariates modelled.

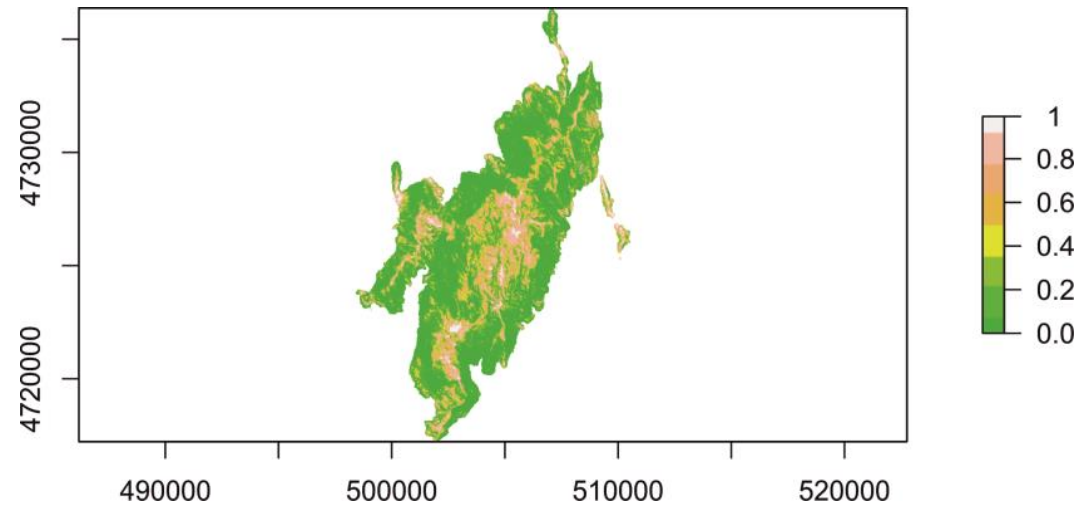

Figure 7. Predicted first-order intensity surface. 


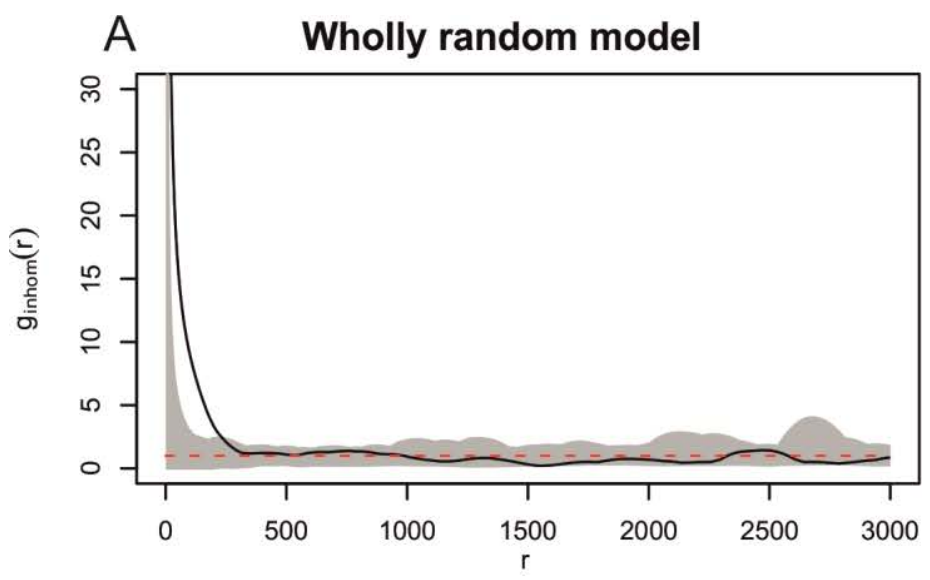

B First-order trend

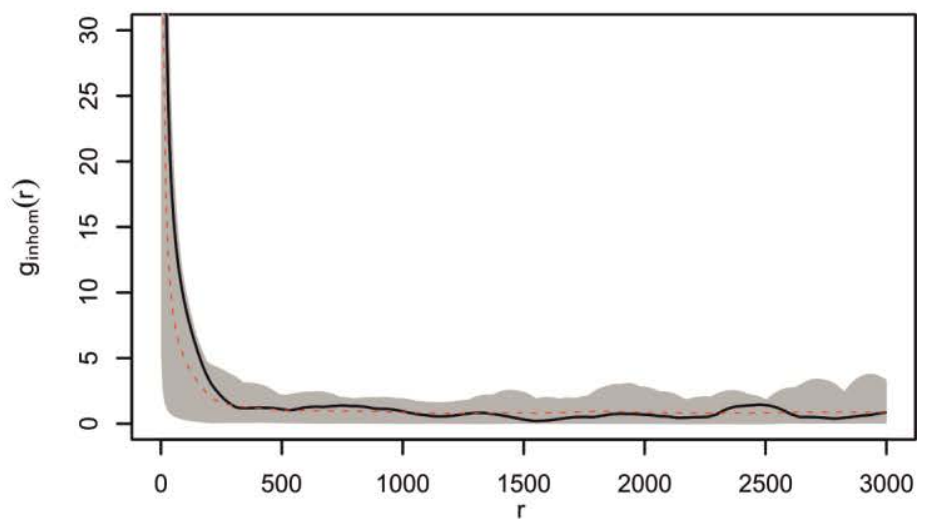

C First and second-order trend

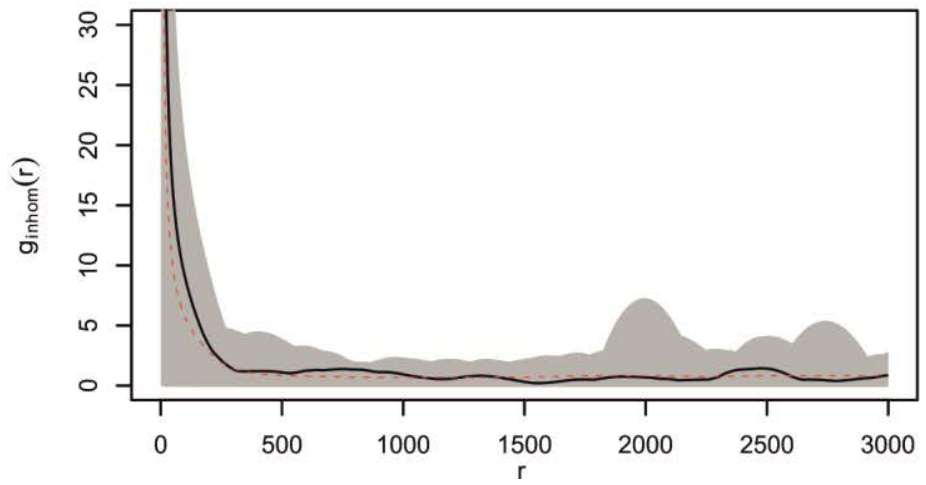

Figure 8. Point process models for the study of second-order effects. A: Pair correlation function with a $95 \%$ envelope from wholly random Poisson process. B: Pair correlation function of the observed sites with a $95 \%$ envelope conditioned on the first-order covariates model. C: Pair correlation function with a 95\% envelope also conditioned on both the first-order covariates and a second-order, area-interaction model $(\mathrm{r}=150 \mathrm{~m})$. 
TABLES

\begin{tabular}{|c|c|c|}
\hline Locational factor & Reference & Covariable setup \\
\hline $\begin{array}{c}\text { Geology } \\
\text { (granite areas) }\end{array}$ & $\begin{array}{l}\text { Leisner 1938; Bello Diéguez et al. } \\
\text { 1982, 1987; Criado Boado, Vaquero } \\
\text { Lastres 1991; Gómez Vila } 2005\end{array}$ & $\begin{array}{c}\text { Rasterisation of } \\
\text { official MAGNA } \\
\text { map from National } \\
\text { Geographic Institute }\end{array}$ \\
\hline $\begin{array}{c}\text { Edaphology } \\
\text { (sites close to tillage } \\
\text { areas) } \\
\end{array}$ & Criado Boado, Grajal Blanco 1981 & $\begin{array}{l}\text { Not modelled in this } \\
\text { work }\end{array}$ \\
\hline $\begin{array}{c}\text { Altitude and slope } \\
\text { (high elevation areas) }\end{array}$ & $\begin{array}{l}\text { López Cuevillas 1973; Criado Boado } \\
1988\end{array}$ & $\begin{array}{l}\text { DEM } 5 \text { m. built } \\
\text { from LiDAR data }\end{array}$ \\
\hline $\begin{array}{l}\text { Topographic } \\
\text { prominence and visual } \\
\text { impact }\end{array}$ & $\begin{array}{c}\text { Criado Boado 1984a; Criado Boado } \\
1988\end{array}$ & $\begin{array}{l}\text { Topographic } \\
\text { prominence index } \\
\text { (local-large scale) } \\
\text { and total viewshed }\end{array}$ \\
\hline $\begin{array}{c}\text { Relation with transit } \\
\text { network }\end{array}$ & $\begin{array}{l}\text { Díaz Sanjurjo 1903; Castillo López } \\
\text { 1927; López Cuevillas 1925, 1933; } \\
\text { Maciñeira 1935, 1943-1944; Bello } \\
\text { Diéguez et al. 1982a, 1982b; Criado } \\
\text { Boado, Vaquero Lastres 1991; Vaquero } \\
\text { Lastres 1991-1992, 1993-1994; } \\
\text { Eguileta Franco 1999 }\end{array}$ & $\begin{array}{l}\text { Least cost path } \\
\text { density }\end{array}$ \\
\hline $\begin{array}{l}\text { Relation with water } \\
\text { areas }\end{array}$ & $\begin{array}{c}\text { Vaquero Lastres 1990; Méndez } \\
\text { Fernández 1998; Villoch Vázquez, } \\
\text { 2000; Santos Estévez } 2008\end{array}$ & $\begin{array}{l}\text { Distance to rivers } \\
\text { and topographic } \\
\text { wetness index } \\
\end{array}$ \\
\hline $\begin{array}{l}\text { Relation with other } \\
\text { natural features and } \\
\text { archaeological } \\
\text { remains (petroglyphs) }\end{array}$ & $\begin{array}{l}\text { Filgueiras Rey, Rodríguez Fernández } \\
\text { 1994; Villoch Vázquez 1995, 1998; } \\
\text { Santos Estévez et al. } 1997\end{array}$ & $\begin{array}{l}\text { Not modelled in this } \\
\text { work }\end{array}$ \\
\hline $\begin{array}{c}\text { Relation with } \\
\text { watershed edges }\end{array}$ & Bradley 1991a, 1991b & $\begin{array}{c}\text { Distance to } \\
\text { watershed edges }\end{array}$ \\
\hline
\end{tabular}

Table 1. Variables of the locational model of the megalithic culture in Galicia managed by literature, and setup in a GIS environment. 


\begin{tabular}{|c|c|c|c|c|c|}
\hline \multicolumn{6}{|c|}{ Multivariate regression model } \\
\hline \multicolumn{6}{|c|}{$\begin{array}{l}\text { Initial Model: } \text { site } \sim \text { elevation }+ \text { slope }+ \text { distance to rivers }+ \text { distance to watershed } \\
\text { edges }+ \text { geology }+ \text { routes }+ \text { topographic prominence index }(500)+\text { total viewshed }\end{array}$} \\
\hline \multicolumn{6}{|c|}{$\begin{array}{l}\text { Final Model: site } \sim \text { elevation }+ \text { slope }+ \text { distance to watershed edges }+ \text { geology }+ \text { routes } \\
+ \text { total viewshed }\end{array}$} \\
\hline Coefficients & Estimate & Std. Error & z value & p value & $\begin{array}{c}\begin{array}{c}\text { Significance } \\
\text { values }\end{array} \\
\end{array}$ \\
\hline (Intercept) & $6.495 \mathrm{e}+00$ & $1.005 \mathrm{e}+00$ & 6.463 & $1.03 \mathrm{e}-10$ & $* * *$ \\
\hline elevation & $-5.953 e-03$ & $1.282 \mathrm{e}-03$ & -4.642 & $3.44 \mathrm{e}-06$ & $* * *$ \\
\hline slope & $-3.225 \mathrm{e}-01$ & $3.083 \mathrm{e}-02$ & -10.461 & $<2 \mathrm{e}-16$ & $* * *$ \\
\hline $\begin{array}{l}\text { distance to } \\
\text { watershed edges }\end{array}$ & $-2.309 e-03$ & $4.748 \mathrm{e}-04$ & -4.863 & $1.15 \mathrm{e}-06$ & $* * *$ \\
\hline geology & $-5.364 \mathrm{e}-01$ & $1.781 \mathrm{e}-01$ & -3.012 & 0.002595 & $* *$ \\
\hline routes & $7.115 \mathrm{e}+00$ & $2.744 \mathrm{e}+00$ & 2.592 & 0.009531 & $* *$ \\
\hline total viewshed & $5.196 \mathrm{e}-05$ & $1.389 \mathrm{e}-05$ & 3.740 & 0.000184 & $* * *$ \\
\hline \multicolumn{6}{|c|}{ 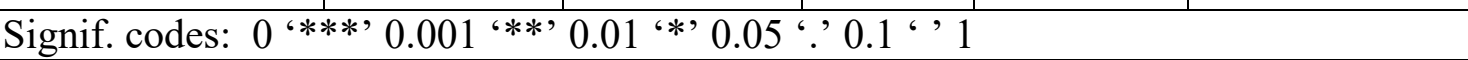 } \\
\hline \multicolumn{6}{|c|}{$\begin{array}{l}\text { (Dispersion parameter for binomial family taken to be } 1 \text { ) } \\
\text { Null deviance: } 892.34 \text { on } 123 \text { degrees of freedom } \\
\text { Residual deviance: } 462.05 \text { on } 117 \text { degrees of freedom } \\
\text { AIC: } 473.48 \\
\text { Number of Fisher Scoring iterations: } 5\end{array}$} \\
\hline
\end{tabular}

Table 2. Results of the multivariate regression model. 